\title{
Memandang Wajah Negara Islam Di Indonesia: Usaha Pembelajaran Sejarah Melalui Materi Konflik
}

\author{
Roni Tabroni, Mumuh Muhsin Zakaria, Reiza D. Dienaputra, R. M. Mulyadi \\ Departemen Sejarah, Fakultas Humaniora, Universitas Padjadjaran
}

\begin{abstract}
Abstrak
Wajah negara Islam di Indonesia telah mengalami perubahan sejak pertama berdengung di masa Darul Islam hingga sekarang yang dibawa oleh Hizbut Tahrir. Perubahan terletak dalam bentuk gerakan, visi-misi, ide, undang-undang yang berlaku dan sistem pemerintahan yang dianut serta di adopsi. Konflik yang menyertai perubahan tersebut pun berwajah tak sama. Mulai dari konflik intern umat beragama, antar umat beragama hingga yang menggerogoti kesatuan dan persatuan bangsa Indonesia. Penelitian ini bertujuan untuk memberikan pengetahuan tentang variasi pembelajaran sejarah melalui materi konflik dan menumbuhkan kesadaran sejarah peserta didik. Penelitian menggunakan metode kualitatif. Sumber data berasal dari informan, aktivitas pembelajaran, dan dokumen perangkat pembelajaran. Hasil penelitian menunjukkan bahwa pembelajaran sejarah melalui materi konflik yang berkenaan dengan usaha pendirian Negara Islam Indonesia berkontribusi dalam hal kesadaran sejarah. Sebuah kesadaran sejarah tentang pentingnya persatuan dan kesatuan, pengorbanan dan cinta tanah air. Dengan belajar dari konflik tersebut peserta didik juga dapat membuat langkah antisipatif supaya kejadian serupa tidak terulang lagi di masa mendatang. Selain itu, hasil penelitian juga menunjukkan apresiasi yang muncul dari peserta didik terhadap materi yang lingkupnya dekat dengan mereka, terutama tema-tema agama terkategori sangat baik.
\end{abstract}

\section{Kata Kunci: Negara Islam, Konflik, Pembelajaran, Sejarah}

\section{Pendahuluan}

Pendidikan sejarah di sekolah pada masa sekarang menghadapi tantangan dan tuntutan yang tidak mudah. Pendidikan sejarah ditantang dan dituntut untuk berkontribusi dalam menumbuhkembangkan kesadaran sejarah (historical consciousness) peserta didik. Baik posisinya sebagai anggota sekolah, masyarakat, maupun warga negara. Di dalam hal ini pendidikan sejarah dituntut untuk memperhatikan pengembangan keterampilan berfikir dalam proses pembelajarannya. Melalui pendidikan sejarah peserta didik ditantang untuk menelaah keterkaitan kehidupan yang di alami sendiri, masyarakat dan bangsanya sehingga mereka tumbuh menjadi generasi muda yang memiliki kesadaran sejarah. Sebuah kesadaran untuk mendapatkan inspirasi atau pun hikmah dari kisah-kisah pahlawan, konflik atau tragedi nasional yang terjadi di masa lampau. Pada akhirnya mendorong terbentuknya pola pikir rasional-kritis-empiris yang berujung pada sikap mau menghargai nilai-nilai kemanusiaan. Termasuk mempertebal semangat kebangsaan dan rasa cinta tanah air, tanpa mengabaikan rasa kebersamaan dalam kehidupan antar bangsa dalam semesta global. Kesadaran sejarah tidak dapat tumbuh dengan sendirinya tetapi harus diupayakan. Proses penyadaran sejarah dapat dilakukan secara bertahap 
melalui pembinaan, baik secara formal maupun non-formal. Membangun dan menumbuhkembangkan kesadaran sejarah diharapkan dapat mendorong dan memotivasi generasi muda untuk mencapai tingkat kehidupan yang lebih baik (Subagyo, 2010).

Unsur-unsur kesadaran sejarah meliputi kepekaan terhadap bagaimana waktu dan tempat lain berbeda dengan waktu dan tempat kita sendiri, kesadaran akan kesinambungan dasar di dalam kejadian sejarah manusia sepanjang masa, kemampuan untuk mencatat dan menjelaskan perubahan-perubahan yang berarti dan kepekaan terhadap sebabmusabab kausalitas yang beraneka macam, kesadaran bahwa semua sejarah yang tertulis adalah suatu rekonstruksi yang tidak sempurna dalam mencerminkan masa lampau sebagaimana yang sungguhsungguh telah terjadi.

Belajar berfikir secara sejarah seperti di atas merupakan suatu proses berangsur-angsur melalui sejumlah tahaptahap perkembangan. Paling sedikit terdapat empat tahap yang dilalui, diantaranya Pertama, sejarah sebagai fakta, Kedua, sejarah sebagai sebab-akibat, Ketiga, sejarah sebagai kompleksitas, dan Keempat, sejarah sebagai penafsiran/interpretasi (Subagyo, 2010). Hal tersebut harus didukung oleh kemampuan guru sejarah. Seorang guru dalam proses belajar mengajar hendaknya tidak sekadar menyampaikan materi saja, tetapi juga harus berupaya agar materi pembelajaran yang disampaikan menjadi kegiatan yang menyenangkan dan mudah dipahami siswa. Kemudian bagaimana materi pengajaran sejarah dikaitkan dengan peristiwa sejarah di sekitar tempat tinggal peserta didik. Hal ini akan mendekatkan peserta didik dengan materi tersebut.

Guru adalah aspek pertama pemicu dan pemberi motivasi peserta didik untuk belajar sejarah. Sosok guru, walaupun di era kemajuan teknologi kehadirannya dapat digantikan, tetapi untuk pembelajaran sejarah tetap diperlukan. Guru tidak sekadar fasilitator yang memfasilitasi terjadinya proses pembelajaran, tetapi guru adalah seorang desainer bagaimana proses pembelajaran itu harus dan semestinya terjadi. Dalam konteks pembelajaran sejarah yang ideal maka, guru sejarah harus memenuhi beberapa persyaratan.

Persyaratan guru sejarah, antara lain 1). harus memiliki kemampuan akademis terutama penguasaan materi. Kemampuan akademis guru setidaknya diindikasikan oleh latar belakang pendidikan yang berasal dari jurusan sejarah atau pendidikan sejarah. Tentu saja tidak dapat dijadikan jaminan bahwa seorang berlatar pendidikan sejarah pasti memiliki kemampuan akademis dengan baik, tetapi setidaknya di didik untuk hal 
tersebut. Pada kemampuan akademis tersirat guru betul-betul memahami karakter setiap materi, 2). kemampuan didaktik metodik (paedagogis). Kemampuan didaktik metodik adalah kemampuan guru untuk melaksanakan pembelajaran sejarah (Sayono, 2013). Pengembangan kesadaran sejarah peserta didik pun bergantung kepada guru.

Pengembangan kesadaran sejarah peserta didik yang menjadi tujuan utama pendidikan sejarah seakan menemui tembok tebal ketika melihat kenyataan yang terjadi di sekolah sekarang. Pendidikan sejarah diidentikan sebagai pembelajaran yang membosankan di kelas. Baik strategi, metode maupun teknik pembelajaran lebih banyak bertumpu pada pendekatan berbasis guru yang monoton dan meminimalkan partisipasi peserta didik. Guru diposisikan sebagai satusatunya sumber informasi, peserta didik hanya objek pendengar.

Guru seringkali sebagai segala sumber dan pengelola informasi hanya mengajar dengan metode ceramah dan tanya jawab yang konvensional. Sehingga pembelajaran sejarah membosankan. Selain itu juga hanya menjadi wahana pengembangan keterampilan berfikir tingkat rendah dan tidak memberi peluang kemampuan berinkuiri maupun memecahkan masalah. Memahami kenyataan umum pembelajaran sejarah di lapangan tersebut, yang menjadi penyebab utama adalah guru. Untuk itu para guru sejarah di lapangan ditantang untuk memiliki motivasi, keinginan, antusiasme dan kreatifitas mengembangkan dan meningkatkan kompetensi mengajar melalui pengayaan dan penguasaan berbagai model, strategi dan metode pembelajaran sejarah. Banyak hal yang menyebabkan guru tidak memiliki antusiasme atau kreatifitas yang tinggi terhadap pembelajaran sejarah.

Salah satunya adalah ketidaktahuan guru akan tujuan pembelajaran sejarah. Tujuan pembelajaran sejarah menurut Hunt (Hunt, 2007) adalah 1). Untuk memahami masa kini dalam konteks masa lalu, 2). Untuk membangkitkan minat dari masa lalu, 3). Untuk memberikan identitas dari para siswa (kebangsaan), 4). Untuk membantu memberikan murid pemahaman tentang akar dan warisan budaya mereka,

5). Untuk berkontribusi terhadap pemahaman dan pengetahuan peserta didik mengenai negara dan kebudayaan berbeda dalam dunia modern, 6). Untuk melatih pikiran dengan studi disiplin ilmu sejarah, 7). Untuk memperkenalkan siswa metodologi sejarah yang khas, 8). Untuk mendorong bagian lain dari kurikulum, 9). Untuk mempersiapkan siswa menuju kehidupan dewasa. Dari kesembilan tujuan yang dirumuskan oleh Martin Hunt tersebut, ada dua tujuan utama yang harus di dapat peserta didik, yaitu kesadaran sejarah dan memahami ilmu sejarah. 
Kesadaran sejarah ini muncul dalam rumusan tujuan pendidikan sejarah di Indonesia. Dalam rumusan tujuan pendidikan sejarah dinyatakan bahwa pendidikan sejarah bertujuan untuk menyadarkan siswa akan adanya proses perubahan dan perkembangan masyarakat dalam dimensi waktu, dan membangun perspektif serta kesadaran sejarah dalam menemukan, memahami, dan menjelaskan jati diri bangsa di masa lalu, masa kini, dan masa depan ditengah-tengah perubahan dunia (Depdiknas, 2003).

Hal ini juga sesuai dengan apa yang dikemukakan oleh Sartono Kartodirdjo dan Kuntowijoyo (Kartodirdjo, 1992; Kuntowijoyo, 1995). Menurut mereka, tujuan utama belajar sejarah adalah menjadikan seseorang bijaksana. Kebijaksanaan yang hanya akan timbul dari sebuah kesadaran sejarah, baik tentang diri ataupun bangsanya. Hal tersebut kemudian diikuti pendapat Joko Sayono (Sayono, 2013) yang mengidentikkan belajar sejarah sebagai pintu untuk mempelajari dan menemukan hikmah terhadap apa yang sudah terjadi.

$$
\begin{array}{r}
\text { Belajar sejarah adalah belajar } \\
\text { tentang kemanusiaan dalam segala }
\end{array}
$$
aspeknya. Belajar sejarah akan melahirkan kesadaran tentang hakekat perkembangan budaya dan peradaban manusia. Jadi, tujuan belajar sejarah salah satunya adalah melahirkan kesadaran sejarah. Selain kesadaran sejarah, pemahaman akan ilmu sejarah juga merupakan tujuan dari pembelajaran sejarah. Hal ini dapat dilihat dari pendapat Said Hamid Hasan. Menurut Hasan (Hasan, 2012), setidaknya ada dua tujuan penting dari pendidikan sejarah. Pertama, sebagai media yang mampu mengembangkan potensi peserta didik untuk mengenal nilai-nilai bangsa yang terus bertahan, berubah dan menjadi milik bangsa masa kini. Melalui pendidikan sejarah, peserta didik belajar mengenal bangsanya dan dirinya. Sebuah definisi tentang kesadaran sejarah.

Kedua, sebagai wahana pendidikan untuk mengembangkan disiplin ilmu sejarah. Pengembangan disiplin ilmu sejarah ini memiliki dua dimensi pengertian, satu pengembangan ilmu sejarah yang berkenaan dengan aktivitas guru dan pengembangan dalam arti pemahaman peserta didik akan ilmu sejarah. Selain ketidaktahuan guru mengenai tujuan pendidikan sejarah, hal lain yang dianggap remeh adalah kemampuan pengembangan metode.

Ada beberapa faktor guru sering abai dan keliru terhadap pengembangan metode pembelajaran. Dewi Suhartini (Suhartini, 2001) mensinyalir kekeliruan metode pembelajaran sejarah yang dikembangkan guru disebabkan 1). Padatnya materi pelajaran sehingga memungkinkan untuk mengambil jalan pintas, berarti mengabaikan aspek afektif dan psikomotorik, 2). Guru tidak memiliki 
pengetahuan dan keterampilan untuk membelajarkan sejarah yang dapat menarik minat siswa dan 3). Guru cenderung menggunakan satu metode dalam membelajarkan keseluruhan materi, tanpa mempertimbangkan karakteristik dari setiap topik materi yang disampaikan. Pandangan hampir serupa dikemukakan Dyah Kumalasari (Kumalasari, 2005). Menurutnya setidaknya ada empat komponen yang saling berkait dan menjadi penyebab munculnya masalah dalam pembelajaran sejarah, yakni 1). tenaga pengajar sejarah yang pada umumnya miskin wawasan kesejarahan karena ada semacam kemalasan intelektual untuk menggali sumber sejarah, baik berupa benda-benda, dokumen maupun literatur. Pengajar sejarah yang baik adalah mereka yang mampu merangsang dan mengembangkan daya imajinasi peserta didik sedemikian rupa, sehingga cerita sejarah yang disajikan menantang rasa ingin tahu,

2). buku-buku sejarah dan media pembelajaran sejarah yang masih terbatas, 3). peserta didik yang kurang memberikan respons positif terhadap pembelajaran sejarah dan 4). metode pembelajaran sejarah pada umumnya kurang menantang daya intelektual peserta didik. Tanpa bermaksud mengabaikan pentingnya membenahi komponen lain yang telah dikemukakan oleh Dyah Kumalasari. Tetapi pembenahan metode pembelajaran sejarah adalah hal yang paling realistis untuk dilakukan. Hal ini sesuai dengan pendapat I Gde Widja (Widja, 1990) yang menyatakan bahwa apabila kita ingin memperbaiki citra buram dari pelajaran sejarah diperlukan usaha-usaha perbaikan cara mengajar guru sejarah. Pendapat tersebut kemudian diperkuat Sanusi (Sanusi, 1992) yang berkesimpulan bahwa agar sejarah dapat berfungsi, maka metode pembelajaran sejarah di sekolah harus dibenahi.

Pembenahan cara mengajar guru atau metode pembelajaran sejarah menjadi penting karena berkaitan langsung dengan hasil belajar peserta didik. Langkah awal untuk mengembangkan metode pembelajaran sejarah ke arah yang lebih baik adalah berusaha memahami bagaimana seharusnya mata pelajaran sejarah diajarkan. Setidaknya, ada lima unsur pembelajaran sejarah yang harus diimplementasikan:

\section{A. Variatif}

Pembelajaran apa pun yang dilakukan jika monoton pasti membuat siswa jenuh, bosan, dan akhirnya kurang berminat. Hal ini terjadi dalam pembelajaran sejarah. Karena terkonsentrasi pada penerapan metode ceramah kesan yang muncul adalah mata pelajaran sejarah identik dengan metode ceramah, bahkan sebagian besar guru sejarah berasumsi bahwa materi sejarah dapat dipindahkan secara utuh dari kepala guru ke kepala peserta didik 
dengan metode pembelajaran yang sama (Suhartini, 2001).

\section{B. Dari fakta ke analisis}

Pembelajaran sejarah di berbagai sekolah ternyata lebih menekankan pada fakta sejarah dan hafalan fakta seperti pelaku, tahun kejadian, dan tempat kejadian. Idealnya, pembelajaran sejarah bukan sekadar transfer of knowledge tetapi juga transfer of value. Bukan sekadar mengajarkan siswa menjadi cerdas tetapi juga berakhlak mulia. Oleh karena, pembelajaran sejarah bertujuan mengembangkan keilmuan sekaligus berfungsi didaktis.

Menurut Mestika Zed, siswa tidak hanya cukup dijejali kesibukan kognitif menghafal pengetahuan lewat faktafakta yang sudah mati di masa lalu sebagaimana banyak terjadi selama ini (Zed, 2005). Secara tegas Soedjatmoko (Soedjatmoko, 1976) menggariskan bahwa harus dibuang cara-cara mengajarkan sejarah yang mengutamakan fakta sejarah.

Pandangan ini penting diimplementasikan dalam pengajaran sejarah supaya tidak terjadi keadaan yang mana siswa tidak berhasil sampai taraf kemampuan untuk melihat dan berpikir secara historis, tetapi pengetahuan sejarah mereka berhenti dan terbelenggu oleh sekumpulan data, fakta, dan nama orang. Oleh karena itu, pembelajaran sejarah tidak boleh berhenti pada tingkat fakta tetapi harus sampai tataran analisis.

\section{Terbuka dan dialogis}

Praktek pembelajaran sejarah yang tertutup dan monoton berpotensi membawa siswa dalam suasana kelas yang kaku, sehingga memunculkan sikap kurang antusias. Oleh karena itu, guru sejarah wajib mendesain pembelajaran yang bersifat terbuka dan dialogis. Keterbukaan dan dialogis mengharuskan guru sejarah untuk tidak menganggap dirinya sebagai satusatunya sumber kebenaran di kelas. Sebab paradigma teacher centered cenderung membuat suasana kelas menjadi tertutup dan tidak mampu menumbuhkan kreativitas siswa, sudah harus ditinggalkan kemudian beralih ke student centered.

\section{Divergen}

Sejalan dengan pembelajaran sejarah yang menekankan pada analisis dan dialogis, penerapan prinsip divergen sangat penting agar pembelajaran sejarah terhindar dari kecenderungan yang hanya menyampaikan fakta sejarah. Artinya, pembelajaran sejarah menghendaki pemecahan masalah dengan memberi peluang kepada siswa untuk menganalisis dan melahirkan banyak gagasan. Dengan demikian tidak cukup sekadar guru menanyakan "Siapa tokoh proklamator Negara Islam Indonesia?", melainkan harus 
dikembangkan menjadi "Mengapa Kartosoewiryo memproklamasikan Darul Islam/Negara Islam Indonesia?".

\section{E. Progresif}

Pembelajaran sejarah perlu didasarkan pada prinsip progresif. Seperti dinyatakan I Gde Widja (Widja, 1992), perspektif baru pendidikan sejarah harus progresif dan berwawasan tegas ke masa depan. Apabila sejarah hendak berfungsi sebagai pendidikan, maka harus dapat memberikan solusi cerdas dan relevan dengan situasi sosial dewasa ini. Penekanan prinsip ini merupakan pengewejantahan mata pelajaran sejarah dengan watak tridimensional.

\section{Gde Widja (Widja, 1989)} kemudian memberi rambu-rambu untuk proses pembelajaran sejarah di sekolah dengan menawarkan beberapa metode yang dapat dilaksanakan oleh guru, metode tersebut antara lain:

\section{Metode Reseptif}

Ceramah, bercerita, membaca, mendengarkan radio/tape recorder, melihat film, slide atau model. Metode reseptif merupakan penyampaian informasi satu arah melalui cara tertentu. Pihak guru dan pihak lain seperti buku atau film sebagai pemberi informasi dan murid sebagai pihak penerima.

2. Metode diskusi

3. Metode Discovery/Inquiry
4. Metode pengajaran sejarah di luar kelas, misalnya widya wisata dengan guide, widya wisata mandiri, dan perkemahan sejarah.

\section{Simulasi dan sosiodrama}

\section{Selain metode sejarah, hal lain yang} harus diperhatikan oleh guru menurut Kartodirdjo (Kartodirdjo, 1992) adalah penggunaan pendekatan lokosentris dalam pembelajaran sejarah, yakni pembelajaran sejarah dengan berpijak pada sejarah lokal. Guru harus memahami prinsip paralelisme waktu dalam penyajikan peristiwa, dan juga harus memahami sejarah lokal. Dengan demikian, guru akan selalu menghubungkan peristiwa nasional dengan peristiwa di daerah tempat dia bertugas.

Misalnya, ketika membahas konflik yang terjadi akibat pemberontakan DI/TII, guru juga menjelaskan pada saat yang bersamaan di daerah dia bertugas apakah terjadi konflik serupa. Keterkaitan materi dan pembahasan akan melibatkan tidak hanya pikiran tetapi juga emosional sehingga akan melahirkan kesadaran adanya kesinambungan sejarah masa lalu dengan apa yang terjadi sekarang.

Berdasarkan keterangan tersebut, tujuan dari penelitian ini adalah untuk mengetahui dan menganalisis pembelajaran sejarah materi konflik pada pokok bahasan Perjuangan Menghadapi Ancaman Disintegrasi Bangsa subbab Pemberontakan DI/TII

(Darul Islam/Tentara Islam Indonesia). Selanjutnya hubungannya dengan 
kesadaran sejarah siswa dan melihat bagaimana apresiasi siswa terhadap materi tersebut setelah pembelajaran. Materi konflik dipilih karena begitu banyak konflik yang terjadi di Indonesia. Mulai dari konflik di Kerajaan Majapahit sampai masa orde baru. Konflik adalah unsur yang tidak mungkin dihindarkan dalam sebuah perubahan sosial.

Konflik adalah ekspresi heterogenitas kepentingan, nilai, dan keyakinan sebagai akibat dari perubahan sosial. Konflik merupakan proses yang bersifat instrumental dalam pembentukan, penyatuan dan pemeliharaan struktur sosial. Konflik dapat menetapkan dan menjaga garis batas antara dua atau lebih kelompok. Konflik dengan kelompok lain dapat memperkuat kembali identitas kelompok dan melindunginya agar tidak lebur kedalam dunia sosial sekelilingnya (Margareth, 2004).

Konflik begitu mendominasi dalam arus sejarah negeri ini tetapi masih sedikit yang kemudian menjadikan konflik sebagai perangkat untuk mengmbangkan kesadaran sejarah peserta didik. Istilah konflik mencakup definisi yang luas berkisar mulai dari pemogokan industrial sampai pada persaingan, dan sikap tidak menyukai atau tidak senang dari sekelompok orang atau individu. Konflik terjadi apabila pencapaian tujuan suatu kelompok/individu terhalangi oleh kepentingan kelompok lain/individu lain.
Kebanyakan bentuk konflik muncul ketika dua pihak atau lebih berupaya untuk mencapai tujuan-tujuan yang sama sekali bertentangan satu sama lain. Pencapaian tujuan pihak pertama menyebabkan pihak kedua tidak dapat mencapai sasarannya dan begitu pun sebaliknya. Konflik terjadi karena banyak faktor dan dapat terjadi sewaktu-waktu apabila muncul suatu hal yang memicu terjadinya konflik tersebut.

Ruang lingkup konflik yang akan dibahas dalam penelitian ini adalah tentang Perjuangan Menghadapi Ancaman Disintegrasi Bangsa subbab Pemberontakan DI/TII (Darul Islam/Tentara Islam Indonesia). NII muncul pertama kali di Jawa Barat tepatnya di Tasikmalaya dipimpin oleh Sekarmadji Marijan Kartosuwiryo. Kartosuwiryo memproklamirkan berdirinya Negara Islam Indonesia pada 17 Agustus 1949. Sehingga tidak mengakui Republik Indonesia dan menyatakan bahwa seluruh wilayah Jawa Barat sebagai wilayah kekuasaannya.

Pemberontakan ini muncul sebagai reaksi akibat adanya perundingan Renville yang dianggap merugikan pihak Indonesia. Salah satu poin persetujuan Renville yang ditolak Kartosuwiryo dan pengikutnya adalah keharusan hijrah semua pasukan TNI dari daerah kantong-kantong gerilya ke wilayah yang dikuasai Indonesia. Pemberontakan ini meluas ke Jawa Tengah dengan pimpinan Amir Fatah dan Kiai Mahfud Abdurahman, ke Aceh dengan 
pimpinan Daud Beureuh, dan ke Sulawesi Selatan dengan pimpinan Kahar Muzakar. Gerakan NII di Jawa Barat berhasil ditumpas oleh operasi militer yang dimulai sejak tanggal 27 Agustus 1949. Operasi ini kemudian dinamakan operasi pagar betis. Sebab menggunakan ribuan orang untuk mengepung gunung tempat Kartosuwiryo dan pengikutnya bersembunyi. Perlawanan mereka berakhir pada 4 Juni 1962 Kartosuwiryo berhasil ditangkap di Gunung Geber di daerah Majalaya oleh pasukan Siliwangi.

Tertangkapnya Kartosuwiryo tidak serta merta mematikan usaha pendirian Negara Islam Indonesia yang terbukti muncul kemudian. Kemunculan Masyumi, NII KW IX dan Hizbut Tahrir Indonesia membuktikan usaha pendirian Negara Islam di Indonesia masih akan ada dan berpotensi menimbulkan konflik. Konflik yang dulu pernah memakan ribuan korban sesama anak bangsa.

\section{Tinjauan Pustaka}

Penelitian ini muncul berdasarkan pada penelitian lain yang memiliki tema sejenis, di antaranya:

1. Artikel karya Abdurahman Khubaib, Hamdan Tri Atmaja, dan Ibnu Sodiq berjudul Kontribusi Materi Konflik dalam Pokok Bahasan Sejarah Lokal Kerajaan Demak Bagi Kesadaran Sejarah Siswa Kelas XI IIS 2 SMA Islam Sultan Agung 2 Jepara yang terbit pada jurnal
Indonesian Journal of History Education, 5 (1) tahun 2017. Artikel tersebut memberikan kesimpulan awal bahwa kesadaran sejarah siswa terbangun cukup signifikan apabila tema atau peristiwa yang terjadi berupa konflik dan terjadi di sekitar wilayah mereka (Khubaib, Atmaja, \& Sodiq, 2017).

2. Buku berjudul History Education and Conflict Transformation: Social Psychological Theories, History Teaching and Reconciliation dan diedit oleh Charis Psaltis, Mario Carretero dan Sabina Cehajic-Clancy yang diterbitkan oleh Palgrave Macmillan pada tahun 2017. Karya ini beberapa tulisan dari beberapa penulis berbicara pendekatan pedagogis pembelajaran Sejarah dan rekonsiliasi sampai perspektif guru dan buku-buku tentang masyarakat pasca konflik dan pasca transisi. Buku tersebut memberikan sumbangsih di antaranya pendekatan dalam pembelajaran sejarah yang berkaitan dengan konflik. Salah satunya menjadikan pembelajaran sejarah sebuah wadah untuk mempromosikan relasi positif antarmasyarakat yang terlibat konflik (Psaltis, Carretero, \& Cehajic-Clancy, 2017). Hal ini yang memberikan landasan bahwa konflik bisa dijadikan sumber pembelajaran sejarah.

3. Artikel karya Ni Putu Indra Rusminiati, Made Putra, dan IB Gede Surya Abadi berjudul Model Pembelajaran Resolusi 
Konflik Berbasis Masalah Kontekstual Berpengaruh terhadap Hasil Belajar IPS Siswa Kelas V SD Gugus 1 Abiansemal, yang terbit pada jurnal Mimbar PGSD, 2 (1) tahun 2014. Penelitian tersebut dapat membuktikan ada pengaruh dari model pembelajaran resolusi konflik berbasis masalah kontekstual terhadap hasil belajar IPS (Rusminiati, Putra, \& Abadi, 2014).

4. Tesis berjudul Teaching History after Violent Conflict: The State of An Emerging Field, karya Rachel Rafferty dari University of North Carolina pada tahun 2013. Tesis tersebut mensurvei pembelajaran sejarah yang muncul pasca konflik kekerasan. Hasil penelitian merekomendasikan pembelajaran sejarah setelah konflik kekerasan yang baik adalah memberi penekanan pembelajaran yang multiperspektif, berbasis dialog, menghubungkan dengan konteks lokal dan global, dan meminta guru memainkan peran fasilitatif (Rafferty, 2013).

\section{Metode Penelitian}

Metode yang dipakai dalam penelitian ini adalah penelitian kualitatif. Metode penelitian kualitatif menurut Moleong (2010) adalah penelitian yang bermaksud untuk memahami fenomena tentang apa yang terjadi pada subjek penelitian, misalnya perilaku, persepsi, motivasi, tindakan, secara holistik dan dengan cara deskripsi dalam bentuk katakata dan bahasa, pada konteks khusus yang alamiah, dan memanfaatkan berbagai metode alamiah. Pembelajaran sejarah melalui materi konflik yang terjadi dalam usaha pendirian Negara Islam Indonesia adalah sebuah fenomena. Oleh karena itu, metode ini dapat menawarkan kesempatan untuk mengidentifikasi persamaan dan perbedaan dalam pengajaran sejarah melalui materi konflik tersebut, tanpa memberikan pengandaian apa yang kemudian akan terjadi.

Metode kualitatif sering disebut sebagai penelitian naturalistic, sebab penelitiannya dilakukan dalam kondisi yang alamiah. Di sebut juga sebagai metode etnografi karena awalnya lebih banyak dipakai untuk penelitian bidang antropologi budaya, disebut sebagai metode kualitatif sebab data yang terkumpul dan analisisnya bersifat kualitatif (Sugiyono, 2013: 13).

Dengan demikian, metode penelitian kualitatif yang berlandaskan pada filsafat postpositivisme berguna untuk meneliti kondisi obyek yang alamiah, (sebagai lawannya adalah eksperimen), yang mana peneliti sebagai instrumen kunci, teknik pengumpulan data dilakukan secara triangulasi (gabungan), analisis data bersifat induktif atau kualitatif dan hasil penelitian lebih menekankan makna dari pada generalisasi (Sugiyono, 2013). Metode penelitian kualitatif kemudian digunakan 
untuk memperoleh gambaran situasi dan kejadian secara kongkret tentang pembelajaran sejarah melalui materi konflik. Sampel penelitian adalah siswa kelas XII IPS 1 dan 2 SMU NU Juntinyuat Indramayu. Kelas XII di SMU NU Juntinyuat terdiri dari empat kelas dengan rincian dua kelas untuk IPA dan dua kelas untuk IPS. Untuk kelas IPA pembelajaran sejarah yaitu mata pelajaran sejarah wajib terdapat dua jam pelajaran tiap minggunya.

Sedangkan untuk kelas IPS pembelajaran sejarah terdiri dari dua mata pelajaran yaitu sejarah wajib dengan dua jam pelajaran tiap minggunya, dan sejarah peminatan dengan empat jam pelajaran tiap minggunya. Pemilihan kelas XII IPS berdasarkan pada materi yang mereka pelajari. Materi tentang usaha pendirian Negara Islam Indonesia muncul pada kedua mata pelajaran sejarah Sejarah Wajib dan Sejarah Peminatan. Pada mata pelajaran Sejarah wajib, materi tersebut muncul pada pokok bahasan perjuangan menghadapi disintegrasi bangsa.

Dalam sub-babnya terdapat pembahasan tentang pemberontakan DI/TII, sedangkan mata pelajaran sejarah peminatan muncul pada pokok bahasan Perjuangan Mempertahankan Integrasi NKRI. Dalam sub-babnya terdapat kajian tentang pemberontakan DI/TII. Kemunculan materi di kedua mata pelajaran sejarah tersebut, akan memberikan waktu pembelajaran yang lebih banyak. Sehingga dapat diasumsikan peserta didik kelas XII IPS lebih memahami materi tersebut. Sumber data dalam penelitian ini diperoleh melalui teknik pengamatan langsung, wawancara dan kajian dokumen. Seperti yang telah terungkap sebelumnya, analisis data yang digunakan dalam penelitian kualitatif adalah analisis teknik triangulasi. Teknik triangulasi dalam penelitian ini terdiri dari dua macam, yaitu triangulasi sumber dan triangulasi metode.

Menurut Patton (dalam Moleong, 2010) triangulasi sumber adalah membandingkan dan mengecek balik derajat kepercayaan suatu informasi yang diperoleh pada waktu dan melalui alat yang berbeda. Dalam teknik ini data yang diambil peneliti terdiri dari berbagai sumber, seperti guru sejarah, perangkat pembelajaran (Silabus dan RPP), beberapa contoh tugas siswa dan peserta didik.

Sedangkan teknik triangulasi metode menurut Patton (dalam Moleong, 2010) terdiri dari dua strategi, yaitu 1). pengecekan derajat kepercayaan penemuan hasil penelitian beberapa teknik pengumpulan data, dan 2). pengecekan derajat kepercayaan beberapa sumber data dengan metode yang sama. Dalam teknik triangulasi ini peneliti mencoba menggali informasi yang sama dengan menggunakan metode yang berbeda sebagai pembanding. 
Hasil Dan Pembahasan

\section{A. Pembelajaran Sejarah Pada Pokok} Bahasan Perjuangan Memertahankan Integrasi Bangsa Sub-bab Usaha

\section{Pendirian Negara Islam Indonesia}

Berdasarkan hasil pengamatan langsung dan wawancara yang dilakukan sesudah aktivitas pembelajaran dapat dirangkum beberapa temuan, yaitu:

1. Perencanaan pembelajaran sejarah tentang konflik yang muncul akibat pemberontakan DI/TII di berbagai wilayah Indonesia, memiliki persamaan dengan perencanaan pembelajaran tentang ancaman disintegrasi bangsa yang lain. Hal ini karena merupakan sub materi dari materi pokok yang sama, yaitu perjuangan menghadapi ancaman disintegrasi bangsa. Materi pokok tersebut mempunyai lima sub materi pembahasan: a). Pemberontakan DI/TII (Darul Islam/Tentara Islam Indonesia), b). Pemberontakan APRA (Angkatan Perang Ratu Adil), c). RMS (Republik Maluku Selatan), d). Pemberontakan PRRI/PERMESTA dan e). Peristiwa G 30 S PKI 1965. Hal yang menjadi titik tekan adalah tujuan pembelajara yang mana tujuan pembelajarannya, selain dapat menguraikan (secara deskriptif) tentang peristiwa dan tokoh-tokoh yang terlibat, juga untuk mengaitkan peristiwa tersebut dengan peristiwa sejenis yang terjadi masa sekarang. Pengaitan tersebut menuntut guru untuk mengetahui tentang usaha-usaha pendirian Negara Islam Indonesia yang muncul di masa sekarang, seperti Hizbut Tahrir Indonesia. Dalam tujuan pembelajaran juga terdapat poin untuk mengambil hikmah dari konflik dalam usaha pendirian Negara Islam Indonesia yang berwujud dalam gerakan DI/TII ini. Hal ini kemudian membawa pembelajaran ini dalam aspek afektifnya. Seperti penguatan persatuan dan kesatuan, cinta tanah air, saling pengertian dan saling menghargai, serta perasaan rela berkorban dan tanpa pamrih. Aspek afektif tersebut lebih terbangun ketika peserta didik bertemu langsung dengan pelaku atau saksi dari peristiwa tersebut, serta mendengar langsung konflik yang menyertai dari gerakan DI/TII tersebut.

2. Ketersediaan sumber belajar sejarah pada pokok bahasan perjuangan menghadapi ancaman disintegrasi bangsa sub-bab pemberontakan DI/TII dapat dikatakan cukup memadai. Sumber belajar yang digunakan di SMA NU Juntinyuat Indramayu adalah buku paket dan internet. Buku paket yang digunakan adalah buku paket Sejarah Indonesia terbitan Kementerian Pendidikan dan Kebudayaan tahun 2015 dengan kontributor naskah adalah Abdurakhman, Arif Pradono, Linda Sunarti dan Susanto Zuhdi. Adapun penelaah buku tersebut adalah 
Bahauddin, Hariyono dan Joko Sayono. Buku paket tersebut cukup baik untuk digunakan sebagai sumber belajar utama. Karena materi yang terdapat di dalamnya komprehensif dan bahasa yang digunakan mudah untuk dipahami oleh siswa. Walaupun padatnya materi (hal ini bisa dilihat dari alokasi waktu tiap pokok bahasan), sehingga membuat peserta didik berat untuk memahami keseluruhan isi buku. Misalnya, materi pemberontakan DI/TII (Darul Islam/Tentara Islam Indonesia) hanya memiliki waktu satu kali pertemuan (2x45 menit). Sumber belajar selanjutnya yang digunakan untuk membahas materi ini adalah internet. Penggunaan internet sebagai sumber belajar sejarah di SMA NU Juntinyuat Indramayu telah berlangsung cukup lama. Di dalam penerapannya selalu mendapat pengawasan penuh guru, baik pemilihan konten ataupun efisiensi pemakaian. Pemilihan internet sebagai sumber belajar sesuai respon terhadap perkembangan zaman dan banyak sudut pandang yang dapat dilihat dari sebuah peristiwa. Pemilihan buku paket dan internet sebagai sumber belajar adalah pilihan yang baik. Meskipun bicara tentang konflik lebih efektif apabila peserta didik dapat mendengar langsung keterangan atau konflik yang terjadi dari pelaku atau saksi peristiwa tersebut. Sehingga menjadikan sumber lisan sebagai sumber belajar selain buku paket dan internet.

3. Secara umum penggunaan media pembelajaran sejarah materi perjuangan menghadapi ancaman disintegrasi bangsa sub-bab pemberontakan DI/TII di SMA NU Juntinyuat Indramayu sudah baik. Hal ini bisa dilihat dari penggunaan film sejarah sebagai media pembelajaran. Pengunaan media film atau video dalam pembelajaran sejarah, selain bisa belajar sambil menikmati film, juga membuat siswa lebih fokus dan konsentrasi dari pada pengunaan media lain, seperti power point.

4. Metode pembelajaran yang digunakan guru dalam pembelajaran sejarah materi perjuangan menghadapi ancaman disintegrasi bangsa sub-bab pemberontakan DI/TII di SMA NU Juntinyuat Indramayu adalah ceramah interaktif, presentasi dan diskusi. Presentasi dan diskusi yang dipilih adalah model Student Facilitator and Explain (Siswa mempresentasikan ide atau pendapat pada rekan siswa lainnnya). Pendekatan ini dipilih sebab dapat mengajarkan nilai kerja sama dan keberanian pada peserta didik. Prosentase penggunaan ketiga metode tersebut disesuaikan dengan kondisi peserta didik. Ceramah interaktif lebih sering digunakan pada kelas yang cenderung mudah untuk memahami pelajaran. Sedangkan metode presentasi 
dan diskusi lebih sering digunakan pada kelas yang cenderung pasif ketika pembelajaran sejarah berlangsung. Selain itu, media yang dirasa cukup efektif adalah study tour dengan pendekatan scientific (pendekatan dengan langkah-langkah mengamati, menanyai, mengeksplorasi, mengasosiasikan dan mengkomunikasikan). Perjalanan sejarah materi ini dapat berupa perjalanan ke tempat di mana pemberontakan itu terjadi (wilayah Tasikmalaya dan sekitarnya) atau ke museum TNI di Bandung.

5. Bentuk pengembangan materi yang seharusnya dilakukan oleh guru adalah dengan menunjukkan bahwa adanya keterkaitan antara pemberontakan DI/TII dengan usaha pembentukan Negara Islam yang lain, seperti kemunculan Hizbut Tahrir Indonesia dan memberikan bukti paralelisme bahwa peristiwa tersebut juga terdapat di Indramayu. Materi tentang konflik yang muncul akibat adanya HTI dapat dicari lewat buku-buku atapun lewat internet. Konflik yang terjadi akibat adanya HTI dapat membuat peserta didik lebih memahami tentang potensipotensi konflik lain yang mungkin muncul ke depannya, khususnya dalam hal memertahankan integrasi bangsa di zaman sekarang. Pada pelaksanaan pembelajaran tentang materi tersebut, guru dapat menyampaikan secara objektif konflik dan potensi konflik yang muncul dari keberadaan HTI.

6. Evaluasi yang dilakukan guru pada materi perjuangan menghadapi ancaman disintegrasi bangsa sub-bab pemberontakan DI/TII di SMA NU Juntinyuat Indramayu terdiri dari tiga cara, yaitu penilaian keseharian, ulangan harian dan tugas. Penilaian keseharian dilakukan guru dengan melihat sikap peserta didik ketika pembelajaran berlangsung. Selain itu, juga memberikan pertanyaan misalnya kuis, apabila ada yang bisa menjawab maka akan mendapatkan nilai. Hal ini dilakukan untuk menilai langsung apakah siswa memahami tentang materi pembelajaran yang baru saja diajarkan. Selanjutnya, apabila metode pembelajaran yang digunakan adalah presentasi kelompok dan diskusi, maka dibuat pemeringkatan kelompok mana yang memiliki kinerja dan kerjasama yang baik. Penilaian tugas terdiri dari tugas berupa proyek, produk, portofolio dan unjuk kerja. Salah satu contoh tugas yang dapat diberikan guru adalah membuat semacam kliping yang berhubungan dengan materi yang telah dipelajari secara individu atau kelompok. Pemberian tugas berbasis proyek tersebut di SMA NU Juntinyuat belum terlaksana. Hal ini dikarenakan padatnya alokasi waktu tiap pokok 
bahasan. Padahal pemberian tugas berbasis proyek dan sejenisnya akan mendukung peserta didik lebih dalam menguasai materi.

\section{B. Kesadaran Sejarah Peserta Didik Kelas XII IPS SMA NU Juntinyuat Indramayu}

Berdasarkan wawancara dengan beberapa peserta didik di kelas XII, dapat diambil kesimpulan bahwa pembentukan kesadaran sejarah dilihat dari aspek kognitif atau pengetahuan dikatakan cukup baik. Hal tersebut dapat dilihat dari mengetahui atau tidaknya mereka mengenai materi perjuangan menghadapi ancaman disintegrasi bangsa sub-bab pemberontakan DI/TII. Hal-hal yang menjadi pertanyaan adalah pengetahuan mereka bukan saja tentang Darul Islam saja, tetapi juga menyangkut gerakan politik Islam lain. Kemudian ingin mendirikan Negara Islam di Indonesia yang muncul kemudian, seperti Masyumi, NII KW IX dan HTI.

Mayoritas sudah memahami bahwa tujuan pembelajaran sejarah bukan hanya untuk mengingat dan mengetahui masa lalu, tetapi untuk mempelajari dan belajar dari masa lalu. Dari data tersebut dapat disimpulkan bahwa mereka bukan hanya mengetahui tentang konflik yang terjadi dalam usaha pendirian Negara Islam di Indonesia, selain itu juga belajar dari peristiwa dan konflik itu supaya tidak terulang lagi di masa mendatang. Selain aspek kognitf, aspek lain yang dapat dilihat dari wawancara dengan beberapa peserta didik adalah aspek afektif. Aspek afektif dalam pembelajaran sangat terkait dengan sikap, emosi, penghayatan atau apresiasi terhadap nilai, norma, serta penghargaan dan sesuatu yang dipelajari. Pembelajaran sejarah yang dilakukan oleh guru dalam ranah afektif dapat membuat peserta didik merasa lebih tertarik terhadap materi yang berkaitan dengan lingkungan sekitar.

Serta hal-hal yang bernilai historis yang mana dalam penelitian ini berkenaan dengan usaha-usaha dari kalangan mereka sendiri (umat Islam) untuk mendirikan Negara Islam di Indonesia. Kepedulian dan perhatian tersebut dapat dilihat dari sikap mereka terhadap gerakan DI/TII dan gerakan lainnya yang sejenis. Sebagian besar menyatakan kesedihan, kekecewaan dan keprihatinan terhadap semua konflik akibat kemunculan gerakan tersebut.

Hal lain yang dapat dipelajari dari sebuah konflik adalah adanya hikmah yang dapat diambil dari peristiwa tersebut, dan usaha-usaha yang harus dilakukan agar tidak terjadi hal serupa di kemudian hari. Selain itu juga, konflik dalam masyarakat harus dipahami sebagai proses dinamika relasi manusia yang bersifat konstruktif (Octavian Hendra Prayitno \& Anjar Mukti Wibowo, 2014). Peristiwa pemberontakan Darul Islam memiliki beragam hal yang dapat diambil pelajaran dan pemahaman. Tujuannya untuk mengambil hikmah dari 
peristiwa sejarah. Khususnya konflik yang berkenaan dengan usaha pendirian Negara Islam Indonesia di kelas XII SMU NU Juntinyuat dikatakan cukup baik. Hal ini dilihat hasil wawancara yang menunjukkan bahwa mementingkan diri sendiri, tidak menghormati pilihan atau pendapat orang lain dan tidak ada toleransi adalah penyebab terjadinya konflik tersebut. Aspek selanjutnya dalam pembelajaran sejarah adalah aspek psikomotorik. Aspek ini berkaitan dengan kemampuan melakukan kegiatan yang bersifat fisik dari berbagai mata pelajaran. Pembelajaran ini lebih menekankan terhadap rasa untuk membentuk keterampilan ketika melakukan kegiatan pembelajaran.

Misalnya, respon peserta didik terhadap peristiwa pemberontakan yang dilakukan DI/TII terhadap perjuangan Pasukan Siliwangi untuk memberantas gerakan tersebut, serta peristiwa jatuhnya korban tatkala konflik kedua belah pihak. Semua itu dapat langsung dirasakan dan di respon peserta didik. Apabila mereka melihat kejadian itu langsung (kunjungan museum) atau dibangkitkan perasaannya melalui kunjungan lapangan ke tempat konflik yang terjadi.

\section{Apresiasi Siswa Pada Pembelajaran} Sejarah Materi Konflik Usaha Pendirian Negara Islam di Indonesia

Pembelajaran sejarah materi pokok perjuangan menghadapi ancaman disintegrasi bangsa sub-bab pemberontakan DI/TII yang dilakukan di kelas XII IPS SMA NU Juntinyuat Indramayu membuat siswa memiliki alternatif belajar sejarah lebih bervariasi. Tergambar dari variasi metode dan media pembelajaran yang dilaksanakan guru di sekolah itu. Selain itu, pemilihan pemberontakan DI/TII dikarenakan kedekatan lingkup materi itu dengan peserta didik (sesama pemeluk agama Islam). Respon yang ditunjukkan peserta didik terhadap sub-bab pemberontakan DI/TII yang telah diajarkan guru dikatakan baik.

Hal ini terlihat ketika mereka ditanya mengenai kesukaan pada mata pelajaran sejarah, utamanya pembahasan materi tersebut. Mayoritas mengatakan tertarik mempelajari sejarah dengan alasan yang bervariatif. Dengan apa yang telah terjadi ketika pemberontakan tersebut meletus, peserta didik dapat belajar bagaimana memastikan kejadian itu tidak pernah terulang dalam aspek kehidupannya masing-masing. Situasi ini menyajikan betapa pentingnya peran seorang guru dalam menjelaskan materi yang lebih spesifik.

Tujuannya supaya hal-hal positif dari kejadian masa lalu dapat tersimpan dalam memori mereka guna dijadikan pembelajaran di masa mendatang. Pembelajaran sejarah yang dilakukan guru di kelas XII IPS SMA NU Juntinyuat Indramayu di mulai dengan adanya perencanaan, pelaksanaan hingga evaluasi. 
Pada tahap perencanaan guru terlebih dahulu menyiapkan silabus, RPP dan perangkat pembelajaran lainnya yang berisi sub-bab tentang pemberontakan DI/TII. Tahap selanjutnya adalah tahap pelaksanaan. Tahap ini terbagi menjadi tiga kegiatan, yaitu kegiatan pendahuluan, inti, dan penutup. Kegiatan pendahuluan terdiri dari orientasi, apersepsi, motivasi dan pemberian acuan tentang materi pemberontakan DI/TII, baik KD, Indikator, KKM dan mekanisme pelaksanaan pembelajaran lainnya.

Pada kegiatan inti ada enam hal yang dipelajari peserta didik, yakni stimulasi (kegiatan literasi), identifikasi masalah (berfikir kritis), pengumpulan data (kegiatan literasi), pengolahan data, pembuktian dan menarik kesimpulan. Pada kegiatan inti peserta didik diajarkan untuk meresapi nilai-nilai yang terdapat dalam SK, KD, dan indikator pembelajaran.

Penggunaan model dan metode pembelajaran yang baik dan menyenangkan, serta media yang menarik sudah diterapkan dengan baik dalam pembelajaran sejarah pokok bahasan pemberontakan DI/TII. Sehingga sebagian besar peserta didik kelas XII IPS mengetahui peristiwa pemberontakan tersebut dan tokoh yang terlibat, meski tidak detail seperti yang tercantum di buku. Hal ini karena alokasi waktu yang minim dan banyaknya materi yang harus diselesaikan dalam pelajaran sejarah.
Sedangkan mereka harus mempelajari selain pelajaran sejarah. Upaya yang dilakukan guru dalam mengatasi itu adalah mengefisienkan secara efektif dalam pemilihan materi yang diajarkan.

\section{Penutup}

\section{Kesimpulan}

Materi konflik memiliki keunggulan dalam hal menumbuhkan kesadaran sejarah peserta didik. Sebab isi materinya memberikan berbagai pembelajaran hidup mengenai harga yang harus dibayar dari suatu konflik. Pembelajaran sejarah materi pemberontakan DI/TII di SMA NU Juntinyuat Indramayu yang telah dilakukan oleh guru telah memberikan pengalaman yang mengharukan berdasarkan mayoritas peserta didik. Melalui materi tersebut mereka dapat mengetahui bagaimana pemberontakan DI/TII terjadi.

$$
\text { Materi sejarah yang berbicara }
$$
tentang konflik juga memiliki banyak nilainilai yang bermanfaat bagi siswa. Seperti nilai persatuan dan kesatuan, pengorbanan, menghargai, dan cinta tanah air. Peserta didik diajarkan tentang bagaimana harga sebuah konflik sehingga memunculkan langkah strategis. Tujuannya supaya kejadian itu tidak terjadi lagi di masa depan. Lebih lanjut, mereka dapat meneladani para tokoh yang telah berjuang mempertahankan integrasi bangsa setelah mendapatkan materi Pemberontakan DI/TII. Sikap teladan yang muncul dari 
pengorbanan dan cinta tanah air yang ditunjukkan oleh tokoh-tokoh yang terlibat. Salah satunya adalah Ibrahim Adjie yang berperan penting dalam penumpasan pemberontakan DI/TII di Jawa Barat. Selain kesadaran sejarah, juga terlihat apresiasi siswa yang baik dalam pembelajaran sejarah dalam materi pemberontakan DI/TII. Hal tersebut terlihat dari kondisi peserta didik di dalam kelas tatkala pembelajaran berlangsung. Mayoritas berfokus kepada penyampaian guru. Data itu di dukung oleh hasil review wawancara yang menyatakan bahwa mayoritas siswa menyukai pembelajaran sejarah berbasis konflik pada materi pemberontakan DI/TII.

\section{Daftar Pustaka}

Depdiknas. (2003). Tujuan Pendidikan Sejarah.

Hasan, S. H. (2012). Pendidikan Sejarah Indonesia, Isu dalam Ide dan Pembelajaran. Bandung: Rizqi Press.

Hunt, M. (2007). A Practical Guide To Teaching History In The Secondary School. New York: Routledge.

Kartodirdjo, S. (1992). Pendekatan Ilmu Sosial dalam Metodologi Sejarah. Jakarta: Gramedia Pustaka Utama.

Khubaib, A., Atmaja, H. T., \& Sodiq, I. (2017). Kontribusi Materi Konflik dalam Pokok Bahasan Sejarah Lokal Kerajaan Demak Bagi Kesadaran Sejarah Siswa Kelas XI IIS 2 SMA Islam Sultan Agung 2 Jepara. Indonesian Journal of History Education, 5(1).

Kumalasari, D. (2005). Sejarah dan Problematika Pendidikan. Istoria, 1(1).
Kuntowijoyo. (1995). Pengantar Ilmu Sejarah. Yogyakarta: Yayasan Bentang Budaya.

Margareth, M. P. (2004). Sosiologi Kontemporer. Jakarta: PT. Raja Grafindo Persada.

Moleong, L. (2010). Metodologi Penelitian Kualitatif. Bandung: PT Remaja Rosdakarya Offfset.

Prayitno, O. H. \& Wibowo, A. M. (2014). Pola Kepemimpinan Kepala Desa Dan Pengaruhnya Terhadap Kehidupan Umat Beragama (Studi Di Desa Balun Kecamatan Turi Kabupaten Lamongan). Agastya: Jurnal Sejarah dan Pembelajarannya, 4(01).

Psaltis, C., Carretero, M., \& Cehajic-Clancy, S. (2017). History Education and Conflict Transformation: Social Psychological Theories, History Teaching and Reconciliation. Palgrave Macmillan.

Rafferty, R. (2013). Teaching History after Violent Conflict: The State of An Emerging Field. University of North Carolina.

Rusminiati, N. P. I., Putra, M., \& Abadi, I. G. S. (2014). Model Pembelajaran Resolusi Konflik Berbasis Masalah Kontekstual Berpengaruh terhadap Hasil Belajar IPS Siswa Kelas V SD Gugus 1 Abiansemal. Mimbar PGSD, 2(1).

Sanusi. (1992). Fungsi Pengajaran Sejarah Sebagai Ilmu. Edisi Pertama. Jakarta: UI-Press.

Sayono, J. (2013). Pembelajaran Sejarah di Sekolah: Dari Pragmatis ke Idealis. Jurnal Sejarah Dan Budaya, 7(1).

Soedjatmoko. (1976). Kesadaran Sejarah dalam Pembangunan. Prisma. Edisi ketujuh. Jakarta: LP3ES.

Subagyo. (2010). Membangun Kesadaran Sejarah. Semarang: Widya Karya Semarang.

Sugiyono. (2013). Metode Penelitian Pendidikan Pendidikan Pendekatan Kualitatif, Kuantitatif, dan R\&D. Bandung: CV Alfabeta. 
Suhartini, D. (2001). Minat Siswa Terhadap Topik-topik Mata Pelajaran Sejarah dan Beberapa Faktor yang Melatarbelakanginya (Tesis).

Program Pascasarjana UPI, Bandung.

Widja, I. G. (1989). Dasar-Dasar Pengembangan Strategi serta Metode Pengajaran Sejarah. Jakarta: Depdiknas PPLPTK.

Widja, I. G. (1990). Dasar-dasar Pengembangan Strategi Serta Metode Pengajaran Sejarah. Jakarta: Depdikbud.

Widja, I. G. (1992). Pendidikan Sejarah Beban atau Kekuatan dalam Kurikulum di Masa Depan. Jakarta: UI-Press.

Zed, M. (2005, Agustus). Karakteristik Berpikir Sejarah. Kompas. 